\title{
SEXUAL CITIZENSHIP AND THE CIVIL UNION ACT 2004
}

\author{
Nan Seuffert*
}

This article analyses the parliamentary debates on the Civil Union Act 2004, which provides for legal recognition of same sex relationships, for stories of national identity. A close reading of the parliamentary debates on the Act suggests that although the supporters and opponents of the legislation seemed to be worlds apart, many told similar stories about New Zealand as a nation, and citizens within that nation, emphasising similar values and aspirations. Both sides told stories of citizens, of New Zealanders, as tolerant and fair, as forwarding-looking progressives who value stable long-term, committed relationships, warm loving communities for children, and strong families and family relationships. Both sides generally saw marriage as a positive institution, a cornerstone of society and a building block for society and the nation. While some talked of existing alternatives to marriage, such as de facto relationships, and there was some recognition that not all marriages are good ones, with a few notable exceptions, there was little mention of critiques of marriage as an institution and little or no positive mention of relationships outside of the paradigm of long-term committed, monogamous relationships. Further, while there were arguments, reflecting a privatisation paradigm, that the Civil Union Act 2004 was not necessary since the rights and duties of same sex couples could be structured using the private law of contract and trusts ( $a$ claim that was debated), there was no suggestion that state recognition of marriage should be abolished, or that long-term heterosexual relationships should be structured through private law.

We finally have in the House legislation that enables couples who are in a committed, stable, and exclusive relationship to have a choice as to the means by which they solemnise their relationship, so that they can have access to the law. It is a mark of a mature and tolerant community. ${ }^{1}$

* JD Boston, LLM VUW, LLM Columbia, Associate Professor, University of Waikato School of Law. I would like to thank the Centre for Law, Gender and Sexuality at the University of Kent for the space and facilities to work on this article, and participants in a workshop there for ideas and comments. Special thanks to Davina Cooper, Claire Young, Susan Boyd and Anisa de Jong. I would also like to thank participants of the Sexuality and Citizenship workshop, hosted and funded by Victoria University of Wellington School of Law, for generous comments on a draft of this article, and Elisabeth McDonald for organising the workshop and for comments and support.

1 Metiria Turei MP, Green (24 June 2004) 618 NZPD 13935. 
When will this Parliament realise that in this bill the beginning of a very deep decaying process is being set in place for future generations? If this bill is passed, today is a day that will dawn in our history as a day that in conjunction with the prostitution reform legislation is an indictment on the people who wish to lower our standards. ${ }^{2}$

\section{INTRODUCTION}

New Zealand, like some other countries in recent years, has introduced legislation providing for legal recognition of same sex relationships. The Civil Union Act 2004 allows recognition of relationships for both same sex and heterosexual couples, and amendments to existing legislation resulting from the related Relationships (Statutory References) Act 2005 mean that same sex couples in civil unions will generally be treated in law in the same manner as married couples, with a few exceptions. For many, the passage of these two Acts is a story of progress for New Zealand along the road to recognition of human and citizenship rights, to abolishing discrimination against gays and lesbians, and to maturity for New Zealand as a nation. Those in favour of the legislation argued, in line with the first quote above, that it was consistent with human rights legislation passed in the previous decade, that it placed New Zealand in the moderate middle of an international trend recognizing same sex relationships, that long-term committed same sex relationships deserve the same legal protections as heterosexual marriages, that civil unions are not the same as marriage, and do not threaten marriage or society. For others the legislation was controversial, as reflected in the second quote above. Those opposing the legislation in parliamentary debates claimed that it was unnecessary to protect human rights, that it was being foisted upon New Zealanders unwittingly, that it would undermine marriage and the fabric of society, begin a deep decaying process, lower standards, threaten children in various ways, and that it was part of a project of "social engineering" being undertaken by a "politically correct" government that did not have a mandate from the people.

Although some of the arguments made in the parliamentary debates are factually inaccurate, and some certainly seem more well reasoned than others, this article is not concerned with which of these arguments are correct, or which side should have won the debate, or whether the two Acts should have been passed. Rather, this article is concerned with the ways in which the debate was structured, and in particular, with the portrayals of New Zealand as a nation in the debates. What stories were told about who New Zealanders are as a community? Who was included in those stories and who was excluded? Which conceptions of marriage and relationships were privileged and which were repressed or erased?

A close reading of the parliamentary debates on the Civil Union Bill suggests that although the supporters and opponents of the legislation seemed to be worlds apart, many told similar stories about New Zealand as a nation, and citizens within that nation, emphasising similar values and aspirations. Both sides told stories of citizens, of New Zealanders, as tolerant and fair, as

2 Bill Gudgeon MP, NZ First (24 June 2004) 618 NZPD 13933. 
forwarding-looking progressives who value stable long-term, committed relationships, warm loving communities for children, and strong families and family relationships. Both sides generally saw marriage as a positive institution, a cornerstone of society, and a building block for society and the nation. While some talked of existing alternatives to marriage, such as de facto relationships, and there was some recognition that not all marriages are good ones, with a few notable exceptions, there was little mention of critiques of marriage as an institution and little or no positive mention of relationships outside of the paradigm of long-term committed, monogamous relationships. Further, while there were arguments, reflecting a privatisation paradigm, that the Civil Union Act 2004 was not necessary since the rights and duties of same sex couples could be structured using the private law of contract and trusts (a claim that was debated), there was no suggestion that state recognition of marriage should be abolished, or that long-term heterosexual relationships should be structured through private law.

This article begins by providing a brief background to the Civil Union Act 2004, its emergence in New Zealand law, and the arguments of those supporting and opposing it. It then discusses theories of nations as imagined political communities, of citizens as bearers of rights within those communities, and of assimilation to the national norms. Next it analyses the parliamentary debates on the Civil Union Bill for stories of national identity, with close attention to what is repressed and erased in those stories. It argues that the parliamentary debates on the Civil Union Bill suggest that the Act will operate to assimilate same sex couples to a shared version of national identity, one in which civil unions are a symbol of progressive recognition of human rights in New Zealand, and in which stable long-term same sex relationships that emulate the preferred types of heterosexual relationships will be recognised as included within the national identity. However, it also argues that assimilation involves a process of recognising and including the "other" to the extent that the other is the same, leaving a residue of difference unrecognised. Same sex relationships are recognised in these debates to the extent that they conform to the national norms. Differences, such as the sexual intimacy of same sex relationships, are erased in the debate, and are left as a mark of the "other", unassimilated. Relationships that do not conform to the norm, as well as challenges to the norm, such as critiques of civil unions or marriage, are repressed or erased. The result is that overall, marriage and long-term, monogamous, committed stable relationships, and in particular heterosexual relationships, are reinforced and reinscribed as the national norm, or "gold standard". 3

\section{BACKGROUND}

New Zealand law, unlike the law in some similar jurisdictions, has since 1993 explicitly prohibited discrimination on the basis of sexual orientation. Such discrimination is prohibited under

3 See Claire FL Young and Susan B Boyd "Challenging Heteronormativity? Reaction and Resistance to the Legal Recognition of Same Sex Partnerships" (Manuscript, University of British Columbia, 2005) 29-30, arguing that demands by gay rights groups for marriage rather than registered domestic partnerships reinforced the symbolic importance of marriage as a "gold standard". 
the Human Rights Act 1993 ("HRA") and the New Zealand Bill of Rights Act 1990 ("BOR"). The BOR section 19 specifies that "everyone has the right to freedom from discrimination on the grounds of discrimination in the Human Rights Act 1993." The HRA section 21(1) lists sexual orientation as an enumerated ground of discrimination. The BOR is not entrenched and does not therefore enable the Courts to strike down legislation on the basis that it discriminates contrary to the BOR. However, the BOR provides in section 6 that legislation must be interpreted, where possible, consistently with the right to freedom from discrimination. Originally the government was given five years to comply with the discrimination provisions in the BOR and HRA; in 2001 the HRA was amended to provide that the discrimination provisions applied to government activity. ${ }^{4}$

In the mid-1990s three lesbian couples were denied marriage licences by the Registrar of Births, Deaths and Marriages. The three couples challenged the denial of licences as an interpretation of the Marriage Act 1955 that discriminated against them on the basis of their sex and sexual orientation. They argued in part that the Marriage Act 1955 did not define marriage and therefore it could be interpreted consistent with the BOR, to allow same sex couples to marry. The plaintiffs were denied relief in the High Court ${ }^{5}$ and appealed to the Court of Appeal. In Quilter v Attorney General three judges of the Court of Appeal agreed that limiting marriage to heterosexual couples did not constitute discrimination on the grounds of sexual orientation. ${ }^{6}$ One judge found that discrimination existed, and one, while declining to decide the issue, recognised that there was discrimination prima facie. ${ }^{7}$ The Court was unanimous that although the Marriage Act 1955 neglected to define marriage, and the legislature did not mention that marriage was intended to be exclusively between a man and a woman when the Act was passed, that intention was clear, and therefore the Act could not be interpreted consistently with the BOR's protection against discrimination. ${ }^{8}$ The Court's message was that any change to marriage law in New Zealand would have to come from the legislature. ${ }^{9}$

The policies of the Labour and Green Parties prior to the 2002 election clearly indicated support for legal recognition of same sex relationships. The Labour policy stated that it would "introduce legislation for civil unions, incorporating rights and responsibilities equivalent to those of marriage,

4 Human Rights Amendment Act 2001, s 6; Human Rights Act 1993, s 20.

5 Quilter v Attorney-General [1996] NZFLR 481 (HC).

6 Quilter v Attorney-General [1998] 1 NZLR 523, 526 (CA) Richardson P, 527-528 Gault J, 557 and 565-570 Keith J.

7 Quilter v Attorney-General, above n 6, 528 and 539 Thomas J, 575-576 Tipping J. See also Paul Rishworth "Reflections on the Bill of Rights after Quilter v Attorney-General" [1998] NZULR 683, 687-88.

8 Quilter v Attorney-General, above n 6, 526 Richardson J.

9 Quilter v Attorney-General, above n 6, 526 Richardson J. 
to give recogntion to same sex (and different sex) relationships."10 The Green Party supported extending marriage to gays and lesbians urgently, stating that discrimination in the treatment of same sex couples is "a shameful blot on the laws of New Zealand."11 A Labour coalition government was formed after the 2002 election.

At about the time the Quilter $v$ Attorney-General case was brought, opposition to same sex marriage among some lesbians (and gay men) was voiced. It was argued that marriage was a patriarchal institution and a site of women's oppression and that women were subordinate to men in marriage. It was also argued that recognition through marriage would privilege the monogamous marriage model over the diversity of existing partnerships and living arrangements. ${ }^{12}$ Some of these arguments reflected feminist scholarly critiques of marriage, "[m]arriage has been shown to endow men with a better lifestyle, greater freedom and more power, while it has the opposite effect on women, limiting, impoverishing, and rendering them vulnerable to abuses of power by their husbands."13 Scholarly arguments have been made that, rather than advocating for inclusion in marriage, lesbians should advocate for the abolition of marriage. ${ }^{14}$ Some of these critiques were first articulated in the eighteenth century. ${ }^{15}$ Other lesbian and feminist scholars argued in favour of same sex marriage, on the basis that it was necessary to achieve equality and that some of the feminist critiques of marriage are not transferable to lesbian and gay marriage. ${ }^{16}$ Some argued in favour of same sex marriage on the basis that it had the potential to disrupt the gendered roles of wife and husband, and transform the institution of marriage. ${ }^{17}$

10 New Zealand Labour Party "Labour on Rainbow Issues" (2002) Press Release.

11 Richard Davies "Greens Support Rights for Same Sex Couples" (26 April 2000) Press Release.

12 Jenny Rankine "For Better or Worse?: The marriage debate continues" (Winter 1996) Issue 210 Broadsheet 11.

13 Rosemary Auchmuty "Same-sex Marriage Revived: Feminist Critique and Legal Strategy" (2004) 14(1) Feminism and Psychology 101, 105.

14 Ruthann Robson Sappho Goes to Law School: Fragments in Lesbian Legal Theory (Columbia University Press, New York, 1998) 149-150.

15 For excellent overviews of these arguments in the context of debates on same sex marriage see Young and Boyd, above n 3, 6-13; Auchmuty, above n 13, 106-111.

16 Celia Kitzinger and Sue Wilkinson "The Re-branding of Marriage: Why We Got Married Instead of Registering a Civil Partnership" (2004) 14(1) Feminism and Psychology 126, 131-137.

17 Nan D Hunter "Marriage, Law and Gender: A Feminist Inquiry" in L Duggan and Nan D Hunter (eds) Sex Wars: Sexual Dissent and Political Culture (Routledge, New York and London, 1995) 107; but see Nancy D Polikoff "We Will Get What We Ask For: Why Legalizing Gay and Lesbian Marriage Will not 'Dismantle the Legal Structure of Gender in Every Marriage"' (1993) 79 Virginia LR 1535. 
In 2004 the Civil Union Bill and the Relationships (Statutory References) Bill were introduced into Parliament. ${ }^{18}$ The Civil Union Act 2004 allows two people of either the same or different sexes to enter into a civil union provided that they are over the age of sixteen, are not within certain prohibited degrees of relationship and are not currently married or in a civil union with someone else. ${ }^{19}$ Civil unions are registered in the same manner as marriages and may be terminated under the Family Proceedings Act 1980 in the same manner as marriages. ${ }^{20}$ While a heterosexual couple may convert from a civil union to a marriage or vice versa, a same sex couple may only enter into a civil union and may not convert to a marriage. ${ }^{21}$ The Relationships (Statutory References) Bill provided for the amendment of over 1000 provisions of about 100 statutes and regulations to provide equal treatment of civil unions and marriages. ${ }^{22}$ However, some unequal treatment remains. For example, while opposite sex marriages entered into overseas are recognised in New Zealand, and the Civil Union Act 2004 provides for some recognition of overseas relationships as civil unions, the legislation does not provide for recognition of same sex marriages entered into overseas as marriages in New Zealand. ${ }^{23}$ The inability of same sex couples to convert a civil union to marriage is another difference. The Adoption Act 1955 was not amended to treat married couples and same sex couples in civil unions equally. ${ }^{24}$ The Civil Union Bill was passed on 9 December 2004 and became effective on 29 April 2005.

The Campaign for Civil Unions (Auckland) Inc, with a core membership of 20 people (mostly gay men) $)^{25}$ and a "broader support group" of 200, strongly supported the Civil Union Bill and the Relationships (Statutory References) Bill on the basis of fairness, equality, ending discrimination

18 (24 June 2005) 618 NZPD 13927, 13951.

19 Civil Union Act 2004, ss 7-10.

20 Civil Union Act 2004, s 7(4); P R H Webb "The Civil Union Bill: Why all the fuss?" (2004) 4 FLJ 262.

21 Civil Union Act 2004, s 18.

22 See Anthony Trenwith "Undermining the sanctity of civil unions?" [2005] NZLJ 25, 26.

23 Civil Union Act 2004, ss 5 and 35(1)(a); Trenwith, above n 22, 26.

24 See Ministry of Justice Same-Sex Couples and the Law - Backgrounding the Issues (Wellington, 1999$) 13$. A married couple may apply jointly to adopt a child but "same-sex couples cannot apply jointly to adopt a child." Human Rights Commission Submission on the Civil Union and Relationships (Statutory References) Bills (Wellington, 2004) 10 and 15. A person in a same sex relationship cannot legally adopt the child of their partner: Re an Application by T [1998] NZFLR 769 (HC).

25 In the United Kingdom and the United States those campaigning for same sex marriage have been principally gay men: Auchmuty, above n 13, 111. For an analysis of gendered positions in support of same sex marriage in Canada see Young and Boyd, above n 3, 15-20. In New Zealand the Quilter v AttorneyGeneral case was brought by three lesbian couples, some of whom later opposed the Civil Union Bill on the basis that it set up a second class of recognition rather than providing for marriage. See below text accompanying n 31 . 
against gays, lesbians and de facto couples and ensuring inclusiveness, respect and tolerance. ${ }^{26}$ Other submissions in favour of the two Bills based support on human rights and equality, recognition of diversity and removal of discrimination. ${ }^{27}$ It was also argued in support that the two Bills would provide greater stability for same sex couples with children, that the government should not impose religious or moral codes on a secular society and that the Bills provided a good nonpatriarchal alternative to marriage. ${ }^{28}$ The majority of submissions, most seemingly from a small religious minority, ${ }^{29}$ opposed the two Bills on the basis that they would lead to bigamy, incest, polygamy, paedophilia, bestiality and necrophilia, that they were contrary to God's law, would be harmful to children, threaten heterosexual marriage, and pose a threat to the nation. ${ }^{30}$

Some lesbians and gay men opposed the Civil Union Bill on the basis that it was not marriage, and did not provide all of the rights of marriage, and that it therefore continued discrimination and treated lesbians and gay men as second class citizens. ${ }^{31}$ They argued for full marriage rights. Marilyn Waring, a former Member of Parliament, international human rights expert and an out lesbian, argued that the Civil Union Bill provided a "separate but equal" regime in which civil unions are not equal to marriage, and is therefore inconsistent with international human rights: "I oppose the Civil Union Bill in its form as a less than equal provision for same sex couples to 'formally solemise their relationship'. Equivalence is not equality."32 She lamented the damage to her image of New Zealand as on the cutting edge of human rights issues, and the political expediency that resulted in the Civil Union Bill as a separate but equal solution to this issue. ${ }^{33}$ One of the plaintiffs in the Quilter $v$ Attorney-General case stated in the media that the Bill was a "retrograde step", in part because opposite sex couples have two choices and same sex couples only one. ${ }^{34}$ She also stated: ${ }^{35}$

26 Campaign for Civil Unions (Auckland) Inc Submission on the Civil Union Bill and the Relationships (Statuory References) Bill <http://www.scoop.co.nz> (last accessed 27 February 2006).

27 Alison Laurie "Report on the Written Submissions to the Justice and Electoral Select Committee on the Civil Union Bill and Relationships (Statutory References) Bill" (Manuscript, Victoria University of Wellington, 2004) 7.

28 Laurie, above n 27, 7.

29 Laurie, above n 27, 3; Civil Union Bill 2004, no 149-2 (Select Committee Report) 9-12.

30 Laurie, above $\mathrm{n} 27,5$

31 Laurie, above n 27,7

32 Dr Marilyn Waring "Submission to the Justice and Electoral Law Select Committee on the Civil Union Bill and the Relationships (Statutory References) Bill" (2004) 1

33 Waring, above $\mathrm{n} 32,2$.

34 Denise Irving "State of the Union" (26 June 2004) Waikato Times Hamilton 3.

35 Irving, above n 34, 3. 
I am absolutely opposed to it, it's a bad egg. If we (the country) are not ready for equal rights, let's wait until we are. We (gay couples) are the only group that does not have equal rights in terms of relationships. This creates another level of relationships. It's a second rate offer. It's ridiculous.

Other gays and lesbians saw the Bill as second best, but a step in the right direction. ${ }^{36}$ The Human Rights Commission's submission on the two Bills stated that it was disappointed that "the Government has not chosen to remedy the exclusion of same sex couples by a simple amendment to the Marriage Act to make it available to both homosexual as well as heterosexual couples", noting that the Bills fell short of complete recognition of the equal and inalienable rights of all humans. ${ }^{37}$ One poll suggested that New Zealanders in general approved of the government's move to legally recognise same sex relationships (56\% to $39 \%$ ) but would not approve of gay marriage $54 \%$ to $40 \%) .{ }^{38}$ Other polls by media sources indicated between $46 \%$ and $64 \%$ support for the Civil Union Bill. $^{39}$

\section{NATIONS, CITIZENSHIP, LAW AND ASSIMILATION}

Recently, scholarship on the construction of nations and national identity has blossomed across a number of disciplines, including law. This scholarship has been useful in making visible the imaginaries, boundaries, shapes and forms of national and individual identity, and the relationships between those identities, the dynamics of power and domination, and sometimes, constructions of race, gender and sexual orientation. While there are numerous theories regarding nations and national identity, Benedict Anderson's argument that nations are imagined political communities has been particularly influential in this type of work. ${ }^{40}$ A nation is imagined because no member can ever know all of those who make up the nation, and therefore each carries a fictional image of the nation. It is an imagined community in the sense that all members of the nation are imagined as part of a "fraternity".

Stories of national identity may be contested, multiple and shifting, although one or some stories may be dominant, and may become entrenched, and remarkably "durable". ${ }^{41}$ At any given time, a

36 Irving, above n 34,3 .

37 Human Rights Commission, above n 24, 10, 15

"Civil Union Bill: What the Readers Say" (5 October 2004) New Zealand Herald Auckland.

39 In the One News Colmar Brunton poll $46 \%$ supported the Bill and $34 \%$ opposed it. In all other polls at least $50 \%$ supported the Bill.

40 Benedict Anderson Imagined Communities: Reflections of the Origins and Spread of Nationalism (Verson, London, 1991). The nation is also imagined as a sovereign state, territorially limited, internally united and free of interference from other nation-states.

41 Carl F Stychin A Nation by Rights (Temple University Press, Philadelphia, 1998) 2. 
nation's prevailing story of its collective identity $i$ its collective identity. ${ }^{42}$ Such stories circulate widely through news media, ${ }^{43}$ may be implicitly or explicitly contained in government policy documents and legislative debates, and may be reflected in legislation and cases. ${ }^{44}$ Stories of national identity promoted by the State are official nationalisms. Cases, especially those brought as part of political action challenging prevailing stories of the nation, may result in decisions that contain stories of official nationalism. ${ }^{45}$ Law and policy reform are therefore integral to the creation and maintenance of both national and individual identities.

As imagined political communities, nations are the stories that are told about collective political identities that shape, embrace and buttress certain images and rights of citizenship and stories that are available for individual identities. ${ }^{46}$ These stories of collective identities typically mask various forms of inequality, exclusion and exploitation. ${ }^{47}$ The inclusion of some identities occurs at the expense of the exclusion of others, and identifying particular national identities serves to repress other possibilities for both national and individual identities, as well as collective and individual differences within the nation. ${ }^{48}$

Citizenship has traditionally been figured as access to a set of static rights as a result of membership within a nation. Those who have been denied rights have argued against second class citizenship, and some scholars argue that Western countries enjoy a history of progress in the expansion of citizenship rights marked by, for example, the granting of the vote to women and progress made as a result of the civil rights movements of the 1960s and 1970s. In this conceptualisation, citizenship concerns the exercise of rights in the public realm. It follows that the idea of "sexual citizenship" is a contradiction in terms; sexual activity is part of the private realm,

42 See Jane Flax The American Dream in Black and White: The Clarence Thomas Hearings (Cornell University Press, Ithaca, 1998) 6.

43 Anderson, above n 40, 46

44 Angela P Harris "Comment: Seductions of Modern Culture" (1996) 8 Yale J L \& Human 213, 214: "in Bowers $v$ Hardwick, Justice White, writing the opinion of the Court, tells ... a story about America as a nation." (citations omitted)

45 Harris, above n 44, 214: "White's opinion [in Bowers v Hardwick] can be seen as the formulation of an 'official nationalism' - a nationalism promoted by the state that represses alternative stories among its citizenry for the purpose of maintaining the power of current elites."

46 Anderson, above n 40, 6; Stychin, above n 41, 1-8; Homi Bhaba "Introduction: narrating the nation" in Homi Bhaba (ed) Nation and Narration (Routledge, London, 1990) 1-8; See Harris, above n 44, 213 (the philosophy of the Enlightenment and the Romantic opposition "shape not only the stories we tell about our individual identities, but also the stories we tell about collective identities.")

47 Anderson, above n 40, 7

48 Margaret Davies Delimiting the Law: 'Postmodernism' and the Politics of Law (Pluto Press, London, 1996) 74-77. 
while citizenship happens in the public sphere. ${ }^{49}$ Both feminists and queer theorists have challenged this public/private divide in relation to women, lesbians and gays. ${ }^{50}$ Claims for the right to marry, for recognition of intimate same sex relationships, cross the divide. Marriage is a public sphere right providing recognition for traditionally private sphere activity. Indeed, it has been argued that even in relation to assumptions concerning sexual citizenship, the public/private dichotomy is a myth. Western states make sexual demands of citizens, "configuring citizenship hierarchically and differentially, protecting asymmetrical sexual access rights, leaving the nonprocreative or sexually "deviant" outside." ${ }^{51}$ Some scholarship refuses to restrict sexual citizenship to a public sphere identity that brackets and marginalises the domestic or private realm. ${ }^{52}$

Stories of nation and images of citizens and citizenship rights are co-constitutive; the determination of citizenship is part of the process of inclusion in, and exclusion from, the nation: : $^{53}$

"Citizen" has never meant "inhabitant." It always counterposes some others who are present but not full citizens - at best, visitors, but usually also racial, ethnic and sexual minorities, slaves, criminals, the lower classes, women, children, the elderly. In our Enlightenment inheritance, the nation is an unstable construct, and ideas of citizenship are deployed, typically, in a hegemonic process whereby outsiders are stigmatized and potential deviants jostled into place.

Here a single history of the progressive expansion of citizenship rights is challenged. Rather, citizenship is continually constructed and reconstructed, co-constitutively with stories of nation, in a process in which outsiders and deviants are always necessary to mark boundaries and provide content, in opposition to the centre. Recognition of sexual citizenship involves deploying ideas about national and individual identity, inclusion and exclusion. It may be a process of recognition of some aspects of identity and repression and erasure of others. In the process national identity may be challenged, reconstructed, reinforced or bolstered.

National identities also intersect with the logic of identity in dominant Eurocentric discourses, which operate on hierarchies of race, gender and sexual orientation. National and individual identities in Eurocentric countries are likely to be shaped around whiteness, maleness and heterosexuality. At the same time, these traits are "unmarked", or part of universal humanity. In the

49 Jeffrey Weeks "The Sexual Citizen" (1998) 15(3-4) Culture and Society 35, 36.

50 Diane Richardson "Constructing Sexual Citizenship: theorizing sexual rights" (2000) 20(1) Critical Social Policy 105, 110; Weeks, above n 49, 36-40; Chris Beasley and Carol Bacchi "Citizen Bodies: embodying citizens - a feminist analysis" (2000) 2(3) Int Fem J Polit 337, 348-350.

51 Davina Cooper "Active Citizenship and the Governmentality of Local Lesbian and Gay Politics" (Manuscript, Kent University) 2-3.

52 Cooper, above n 51, 4.

53 Alan Sinfield "Diaspora and Hybridity: Queer Identities and the Ethnicity Model" (1996) 10 Textual Practice 271, 273. 
dominant discourses to have a "race" is to be not white, those who are white are "unmarked" by race. ${ }^{54}$ Members of dominant groups, whose identities are privileged as conforming to the national norms, are positioned as "unmarked" by race, gender or sexual orientation. The logics of race, gender and sexuality displace these "marks" onto "others", 55 those who are women, lesbians and gay men, or not white.

The logic of assimilation of these "others" to the position of the unmarked subject operates in two steps; the recognition of sameness and the unassimilated residual mark of difference: 56

$[\mathrm{T}]$ he process of assimilation ... requires that which defines the difference between the two elements to remain over as a residue. Hence, although it is possible to conceive formally of an equable process of assimilation in which the original elements are entirely equivalent, the product of assimilation will always necessarily be in hierarchical relation to the residual, whether this be defined as variously, the primitive, the local, or the merely contingent.

The first step of assimilation recognises the sameness of the assimilated subject. The second part of this logic resists the incorporation of difference, leaving the residual difference, in this discussion sexual orientation, as "the primitive, the local, or the merely contingent" ${ }^{57}$ unassimilated. This logic also structures the assimilated sameness hierarchically over the unassimilated difference. ${ }^{58}$ In the analysis below, civil unions assimilate same sex relationships to the extent that they are the same as the norms of heterosexual relationships, leaving residual marks of otherness, such as gay and lesbian sexual intimacy, unassimilated and erased from the national identity.

\section{CIVIL UNION STORIES}

The parliamentary debates on the Civil Union Bill contain countless stories of New Zealand's collective identities, some of which dominate the debates. While those supporting and opposing the Bill at times appear to live on different planets, perhaps surprisingly, much of the debate revolves around claims that the mainstream of New Zealanders support or oppose the Bill due to the traits that they share, and many of the same traits are identified by both sides. This section provides a close analysis of the debates in order to identify and analyse these stories. It begins with passages

54 Ruth Frankenburg The Social Construction of Whiteness: White Women, Race Matters (Minnesota UP, Minneapolis, 1993) 16.

55 Carol Pateman The Sexual Contract (Stanford University Press, Stanford, 1988) 116-153.

56 David Lloyd "Race Under Representation" (1991) 13 Oxford Literary Rev 62, 73.

57 Lloyd, above n 56, 73; Homi Bhaba (1997) "Of Mimicry and Man" in Frederick Cooper \& Ann Laura Stoler (eds) Tensions of Empire: Colonial Cultures in a Bourgeois World (University of California Press, Berkley, 1997).

58 Lloyd, above n 56, 73. 
that explicitly identify and discuss New Zealand as a nation and national identity, and then focuses on individual traits identified by both sides.

\section{A The Big Picture}

The speech introducing a Bill typically positions it for its supporters. The Civil Union Bill, which was to be subjected to a conscience vote, was a government Bill, so the introductory speech can be expected to provide the government's position on it: ${ }^{59}$

Providing for civil union in New Zealand will contribute to achieving the Government's objective of creating a more positive human rights culture. Civil union provides for different-sex couples who want formal recognition of their relationship but for some reason do not wish to marry. Civil union will also address the current situation in which same-sex couples cannot receive legal recognition of their loving and committed relationships.

Our intention is that civil union will be a new legal entity, designed to reflect the diversity of New Zealand society and people's personal choices about their relationships in the $21^{\text {st }}$ century. This is a Bill appropriate to the times, which recognises the reality of relationships instead of attempting to deny their existence.

These quotes tell a story of New Zealand as a progressive nation moving forward into the twenty-first century with expanding human rights protections. This progress is encapsulated in a new legal category, which is appropriate to the new century. This is a story of a forward looking country, dealing with and responding to new times. Providing choice for heterosexual couples who do not wish to marry seems to be the primary focus, with the "current situation" and the "reality" for same sex couples coming second, couched in comparatively flat language. The same sex relationships that are to be recognised are quite specifically those that are "loving and committed".

The leading Opposition party responded to the introduction of the Bill by splitting its time between two members. The second speech started with: ${ }^{60}$

This is not a civil union; this is a civil disgrace ... . This bill will tear the social and moral fabric of New

Zealand society asunder. Let us be clear: this bill is a calculated and carefully promoted strategy to undermine the role of marriage and families as the cornerstone of New Zealand society. It is being promoted by a few powerful Government politicians who are abusing society's trust in them. ... Those members are abusing their position by foisting their type of morality on to the many.

Here allowing civil unions poses the alarming threat of civil disorder, an intact social fabric torn asunder, and society crumbling as the result of the loss of the cornerstones of marriage and the family. The "civil disgrace" invokes the possibility of loss of (God's?) grace for the civil sphere of

59 Hon David Benson-Pope MP, Associate Minister of Justice, Labour (24 June 2004) 618 NZPD 13927. 
the nation, ironically in a secular society. The suggestion seems to be that marriage is the tool for creation of the family, and that families are the cornerstones, or reproducers, of the nation. Undermining the family will therefore result in the undermining of society more generally, and of the nation.

Nations have historically been symbolically figured as domestic genealogies with parallel familial and national discourses. ${ }^{61}$ Hierarchies of gender, race and sexual orientation are integral to both of these parallel discourses: ${ }^{62}$

The metaphoric depiction of social hierarchy as natural and familial - the 'national family', the global 'family of nations', the colony as a '[f]amily of black children ruled over by a white father' - depended in this way on the prior naturalizing of the social subordination of women and children within the domestic sphere.

As McClintock argues, parallel conceptions of family and nation are deeply imbricated in differential hierarchies, which are reproduced and reinscribed when these conceptions are invoked. Debates on the Civil Union Bill that invoke these conceptions reinscribe in national identity not only hierarchies of sexual orientation, but also, implicitly, of gender and race. Seen in this light, the idea that recognition of same sex relationships will undermine the "cornerstones" of society suggests that those cornerstones are hierarchies of gender, race and sexual orientation necessary to retaining dominant groups in power.

These two stories of the meaning of the Civil Union Bill for New Zealand as a nation seem to be diametrically opposed. In one, introduction of civil unions is about forward progress embracing international human rights in a new millennium. In the other, civil unions will result in the crumbling of civilisation as we know it, and degeneration into a dark past of disgrace. The remainder of this section identifies the similarities in the underlying stories and values invoked by both sides of the debate.

\section{B Tolerance}

Both sides insist that New Zealand is a tolerant society and that tolerance supports their position in relation to the Bill. Supporters of the Bill are clear that New Zealand is tolerant and openminded: 63

61 Anne McClintock Imperial Leather: Race, Gender and Sexuality in the Colonial Contest (Routledge, New York, 1995) 358.

62 McClintock, above n 61, 358.

63 Hon David Benson-Pope MP, Associate Minister of Justice, Labour (2 Decemberember 2004) 622 NZPD 17388. 
The passage of this bill will help to foster a positive human rights culture in which human beings, regardless of their sexual orientation, are shown the dignity and respect to which they are entitled. The passage of this bill will remove a form of discrimination that has no place in the inclusive, tolerant, and open-minded society that New Zealand is.

New Zealanders pride themselves on tolerance, on a sense of fairness, and on respect for human rights. ${ }^{64}$

Here tolerance is defined as extending dignity and respect to lesbians and gay men. Discrimination on the basis of sexual orientation is not part of New Zealand's story of collective identity; it has "no place" in New Zealand, and is foreign to the nation. Tolerance is integral to national identity, to a sense of who New Zealanders are collectively.

Opponents of the legislation at times accused its supporters of intolerance of the majority of New Zealanders, or of those who are married or are in favour of marriage: 65

I too would like to see tolerance. I would like to see tolerance towards those who do hold marriage sacred, who do not want a carboncopy mockery of it handed out to people who only want social approval but none of the inherent responsibilities attendant on the Marriage Act. I also want to see respectfulness and loving relationships, but we do not need law for that.

The logic of this argument is difficult to discern; if it exists it may rest on the assumption that recognition of civil unions is intolerant of marriage. However, there is no suggestion by supporters of civil unions that marriage will be abolished and replaced by civil unions, or that marriages will not be tolerated in any other fashion, so this assumption seems flawed. Further, civil unions result in the same legal responsibilities as marriage, so the statement about "people" who do not want responsibilities seems clearly inaccurate. The last statement, that no law is necessary for respectfulness and loving relationships, seems logically to support abolishing marriage. Nevertheless, the speaker impliedly accepts tolerance as a positive value with the initial statement that he would like to see it. He also attempts to persuade others with the accusation that supporters of civil unions are not tolerant, which suggests recognition that tolerance is a widely held trait that is valued.

Other opponents critiqued the idea of tolerance, implying that the legislation was the first step in intolerance to be directed at those who are not supporters of civil unions: 66

Too many New Zealanders fall into the trap of being tolerant, without becoming fully aware of what the issues are really about. When asked if they condone same-sex relationships, most New Zealanders will

64 Nandor Tanczos MP, Green (7 December 2004) 622 NZPD 17454.

65 Marc Alexander MP, United Future (7 December 2004) 622 NZPD 17533.

66 Larry Baldock MP, United Future (7 December 2004) 622 NZPD 17452. 
say they do not object, they want to leave people alone, and they do not want to be judgmental. But when we dig deeper into what this legislation may in fact do over time we find there are some serious issues that will be raised. There is no provision in this legislation to prevent discrimination from being placed upon those who have a different opinion from those who support civil relationships, or same-sex relationships.

This speaker positions "most New Zealanders" as tolerant in the sense of nonjudgmental and without the desire to interfere in other peoples lives. It also warns of tolerance as a "trap" of lack of awareness. This lack of attention, the speaker warns, poses the threat of future discrimination against people who do not support civil relationships. While it constructs tolerance as a national trait, it suggests that tolerance may result in a lowering of defences that will permit a slippery slope of future legislation with a backlash against the tolerant majority. This suggestion is ironic as the legislation being debated seems precisely tailored to reflect the opinion polls, which suggest that a majority of New Zealanders are in favour of civil unions and not gay marriage, and it is civil unions that are proposed in the Bill. While it is true that the Bill does not prohibit the passage of discriminatory legislation in the future, such legislation would also have to be passed by elected representatives, most of whom will also be very attentive to majority positions expressed in opinion polls.

Speakers on both sides of the debate (although predominately supporters of the Bill) told stories of collective community that excluded the fundamentalist religious right, sometimes symbolically encapsulated in the Destiny Church. This is the religious minority that seemed to make the majority of the submissions opposing the Bill, discussed above. ${ }^{67}$ The religious right was positioned as hysterically intolerant and opposed to the Bill, and to previous human rights legislation. This was done at times by aligning it with those who adamantly opposed the 1986 Homosexual Law Reform with prophesies of doom and gloom and the demise of society. Supporters of the Bill argued: ${ }^{68}$

I recall that some churches led the charge against Homosexual Law Reform in the 1980s, hopefully to their regret later on when they were exposed as bigoted and alarmist. The walls of civilisation did not collapse. Civilisation was enhanced. The moral issues of life continued to be debated. And more people were able to be openly involved in a more tolerant and less discriminatory society.

The kind of opinion held by people such as [Destiny Church] Pastor Brian Tamaki and churches of that ilk is not, I would say, reflective of all churches and religions in New Zealand. In fact, I would say that only a glaring minority in this country would share their hateful opinions towards people like myself, and gay and lesbian people. ${ }^{69}$

67 See above text accompanying $\mathrm{n} 29$

68 Matt Robson MP, Deputy Leader, Progressives (9 December 2004) 622 NZPD 17660.

69 Georgina Beyer MP, Labour (24 June 2004) 618 NZPD 13945. 
The uproar over the Civil Union Bill has not been dissimilar to that that occurred almost 20 years ago over the Homosexual Law Reform Bill. There are, of course, some differences most notably, how much better informed people are today. The notable exception to that has been the many arguments proffered in this House from Opposition benches - the wild and woolly phantoms produced, the lame excuses for not supporting something that is so clearly the right course of action, and the almost total lack of intellectual rigour or common humanity. ${ }^{70}$

While few who opposed the Bill specifically positioned the religious right as hysterical, they were careful, for the most part, not to align themselves with the views expressed in the related submissions. Some opposing the Bill did specifically argue that those holding the views of the Destiny Church were a fringe minority: ${ }^{71}$

Virtually every person I know, and the vast majority of them are opposed to this bill, say that the Destiny Church has turned them off. These words have been used to describe the Destiny Church: 'A bunch of telemarketing evangelists, a bunch of Jonestown acolytes, zealots, really scary people, people you wouldn't invite to dinner'.

Positioning Destiny Church and the fundamental religious right as an intolerant minority outside of the tolerant mainstream reinforced occupation of the mainstream by both supporters and opposers of the legislation.

Interestingly and ironically, the Civil Union Bill itself represents both the potential and the limits of "tolerance" as a national trait. Tolerance is a gift of the majority to the minority, always in the control of the majority, and not a right of the minority. It is limited to what the majority can be convinced to tolerate, and is therefore sometimes inconsistent with recognition of minority rights. Consistent with this concept of tolerance, the Bill was closely tailored to public opinion, as the polls discussed above indicate. ${ }^{72}$ As pointed out by those who critiqued the Bill as providing a "second class" option for same sex couples, and by the Human Rights Commission, it does not provide full equality. ${ }^{73}$ Asking whether it would be "fair" or "tolerant" to have a law that stated that members of different races, Maori and Pakeha, or Maori and Chinese, for example, could not marry, but only enter into a civil union, might highlight the injustice of this inequality. ${ }^{74}$ It has been argued that such a two-tier system is so obviously unequal that it can only lead inevitably to extending marriage to same sex couples. ${ }^{75}$ The limits to equal treatment, such as recognition of overseas marriages,

70 Hon David Benson-Pope MP, Associate Minister of Justice, Labour (9 December 2004) 622 NZPD 1760.

71 Ron Mark MP, NZ First (7 December 2004) 622 NZPD 17532.

72 See above text accompanying n 38.

73 Human Rights Commission, above n 24, 6, 10, 13.

74 See Kitzinger and Wilkinson, above n 16, 133-135.

75 Auchmuty, above n 13, 119. 
adoption and the inability to convert a civil union to marriage represent the limits of tolerance and mark the boundaries of New Zealand's national identity.

\section{Long-term, Stable, Exclusive Relationships}

The debates widely applauded long-term monogamous stable relationships as the best relationships, and accepted that marriage was the preferred model for recognition and engagement in these relationships. For example, supporters of the Bill argued:

We are simply recognising a situation that already exists, which is that gay people can have long-term, committed relationships, and we are simply allowing the law to recognise that. ${ }^{76}$

The passage of this bill will remove a form of discrimination that is keenly felt by Kiwis who have been living quietly in longterm, loving, same-sex relationships in our communities. ${ }^{77}$

We are not seeking marriage, with this bill; we are seeking a civil union. This is part of the cornerstone of the foundation of our society - to build strong family relationships to help maintain the society we live in. In a country in the modern world, we should be able to enjoy equal opportunity to contribute to that, no matter what our gender or our status may be. We actually preserve and uphold the institution of marriage so that it is not touched. ${ }^{78}$

These are just a few of the passages commending long-term stable relationships. The second quote includes same sex couples living quietly in long-term relationships as part of the collective identity of "Kiwis". The last quote in this group positions relationships recognised as civil unions as part of the cornerstone of society; it agrees with many opposed to the Bill that strong family relationships are necessary to the maintenance of the current society, includes civil unions in the category of those types of relationships, and explicitly argues that the Civil Union Bill preserves and upholds the institution of marriage rather than undermining it. These quotes all position long-term stable relationships, assumed to be like marriage, as the paradigm to which civil unions aspire.

Opponents of the Bill also argued that stable long-term relationships were important. They argued that recognition of civil unions would undermine long-term relationships: ${ }^{79}$

What this bill is doing is casualise relationships. This trend has been happening in this country for 30 years, and we can see the damage it has done to families.

This quote seems to argue that the Bill itself will "casualise" relationships, which it states, is damaging to families. By implication then, relationships that are not casual are preferred. Since the

76 Nandor Tanczos MP, Green (7 December 2004) 622 NZPD 17518.

77 Hon David Benson-Pope MP, Associate Minister of Justice, Labour (2 December 2004) 622 NZPD 17388.

78 Georgina Beyer MP, Labour (7 December 2004) 622 NZPD 17448.

79 Brian Connell MP, National (24 June 2004) 618 NZPD 13930. 
Act provides that civil unions may be terminated in the same manner as marriage this argument seems difficult to support. Indeed, it will be more difficult for people in civil unions to end their relationships than for people not in civil unions. To the extent that the Act provides for or encourages people who would not otherwise do so to enter into legally recognised relationships, it would seem that rather than casualising relationships the Act must formalise them. Nevertheless, the dichotomy that the quote creates is fairly clear; casual relationships are bad and damage the family, and long-term stable relationships are good.

These next two quotes also accept the premise that long-term committed relationships are important and then question whether the Civil Union Bill will provide for or recognise those relationships:

We encourage lifelong and exclusive relationships because we believe as a society that for the nurturing of the next generation it is in the best interests of society that there are stable environments in which to raise children. The trouble with the Civil Union Bill is that we do not know whether that culture will be there. We do not know whether in fact we will have lifelong, exclusive relationships for the nurturing of children. 80

To use the Government's own terms, a new legal relationship will be established recognising the diversity of relationships, and enabling loving and committed couples to formalise their relationship without getting married. Well, this bill does absolutely nothing to define any kind of loving and committed relationship. This bill says nothing about long-term commitment. This bill says nothing about stability. ${ }^{81}$

Of course, marriage does not guarantee life long exclusive relationships for the nurturing of children. Nor does the Marriage Act 1955 define loving and committed relationships, or say anything about long-term commitment or stability. Instead, the assumption is that people enter into marriages and will enter into civil unions because they intend to have a long-term relationship and are committed to that relationship.

Some speakers explicitly tied stability in relationships to stability in the nation. This link seems to again position the family and relationships as the cornerstones of society: ${ }^{82}$

Others who have conscience votes in this House should note that if the bill passes it will undermine a stability that has been the foundation of this country. Moral fibre and virtue seem to be irrelevant, and this bill will certainly erode, disrupt, and create a decay in the family structure as we see it today, which has always been the hallmark of this nation.

80 Murray Smith MP, United Future (7 December 2004) 622 NZPD 17442.

81 Stephen Franks MP, Act (7 December 2004) 622 NZPD 17475-76.

82 Bill Gudgeon MP, NZ First (7 December 2004) 622 NZPD 17447. 
Stability here is of both the relationship and the nation; indeed stability in relationships seems to be assumed to be necessary for national stability, and both are highly valued. However, rather than recognising existing stable relationships that will increase national stability, this speaker argues that recognition of civil unions is a backwards, degenerate step that will lead to the erosion of the family, civilisation and the nation.

\section{Erasing Sexual Intimacy?}

Although the Civil Union Act is about the recognition of same sex sexual relationships among lesbians and gay men, and supporters of the Bill argued that such relationships can have the same qualities as successful long-term marriages, positive statements about gay and lesbian sexuality or sexual intimacy did not feature widely in the debates. Instead, there were moves by both supporters and opponents of the Bill that seem to suggest a desire to erase and make invisible the sexual intimacy of lesbians and gay men.

Carl Stychin has argued that nations have historically been constituted in gendered and sexualised terms; fixed and unchanging sex and gender roles were important and anything undermining that fixity was constructed as the nation's other. ${ }^{83}$ He argues that threats to a nation's existence may be frequently translated into sexualised terms; same sex sexuality is deployed as the alien other and linked to conspiracy, recruitment, opposition to the nation and ultimately a threat to civilisation. ${ }^{84}$ This positioning was clearly evident in both the second quote at the beginning of this article and the leading Opposition response to the introduction of the Bill, discussed above. ${ }^{85}$ Stychin also argues that "homosexual" signified the confusion of the sexes and a sexual excess. Sex role confusion was ascribed to those most clearly defined as outside the nation, namely othered races. Some homosocial behaviour is constructed in a non-sexual fashion so as to absorb it within the national character. ${ }^{86}$ To the extent that lesbians and gay men are figured as encapsulating sexual excess, which is a threat to the nation, erasing the sexual intimacy of same sex relationships is an attempt to remove the threat and reproduce and reinscribe fixed gender roles, and to absorb them within the nation.

Opponents of the legislation often mentioned the amendments to the Bill proposed by Richard Worth, which would have allowed any two people, including siblings and friends, and not just those in intimate relationships, to register a civil relationship. Worth described his proposal as a "set of detailed amendments to the Bill that would have enabled, in a very simple way, a next-of-kin

\footnotetext{
83 Stychin, above $\mathrm{n} 41,7,9$.

84 Stychin, above n 41,9

85 See above text accompanying $\mathrm{n} 58$.

86 Stychin, above n 41, 9-10.
} 
relationship structure to be set up and recognised." 87 Worth also argued that "civil unions discriminate against non-sexual relationships." 88

In favour of Worth's amendments it was argued that the issues raised by lesbians and gay men in the submissions could be dealt with by creation of a next-of-kin status that would be broadly available: ${ }^{89}$

I certainly would have no problem with the legal possibility of registering a relationship for the sake of that relationship. I think this issue does not have to be, for instance, a bedroom issue. I think there are lots of relationships that would benefit from establishing clearly the next-of-kin status that the relationship deserves, providing for protection of jointly owned properties, and reflecting the investment over a period of years that has been given to the relationship by providing some legal framework and legal protection around that.

If we had addressed earlier the needs of the homosexual community in terms of issues such as next-ofkin rights, then a measure such as the one Richard Worth promoted would have been the way to go. ... It does not address the wants of the homosexual community, who want same-sex relationships to be seen to be equivalent to opposite-sex relationships, even though opposite-sex relationships have been a fundamental institution in terms of marriage and the rearing of children, and continue to be so in our society. 90

In these quotes there is opposition to recognition of same sex relationships as equivalent to opposite sex relationships; placing same sex relationships in a category with other non-sexual relationships erases recognition of the intimate nature of the relationships. This is made explicit in the first quote with the statement that it does not have to be a "bedroom issue". In the second quote the "needs" and "wants" of the homosexual community are contrasted. The word "wants", like "desires" may evoke intimate sexuality, and it is recognition of this aspect of lesbian and gay relationships that is to be withheld.

Claire Young and Susan Boyd have argued in relation to a similar proposal in Canada that: ${ }^{91}$

The proposal to extend common law partner status to include those in economically interdependent relationships seems to reflect a desire to erase the visibility of lesbian and gay intimate relationships, and possibly to avert their recognition.

87 Richard Worth MP, National (9 December 2004) 622 NZPD 17658.

88 Richard Worth MP, National (9 December 2004) 622 NZPD 17658.

89 Judy Turner MP, United Future (7 December 2004) 622 NZPD 17475.

90 Murray Smith MP, United Future (7 December 2004) 622 NZPD 17591.

91 Young and Boyd, above n 3. 
Aligning same sex relationships with non-sexual interdependent relationships, as proposed by the Worth amendments, erases the sexual intimacy of those relationships.

At least one opponent of the Bill argued not all gay people living together wanted recognition: ${ }^{92}$

It is quite wrong, I suspect, to say that every gay couple is clamouring for this bill. Every couple who live together, perhaps an older couple, for comfort, surely to goodness, and a little bit of security, will be unionised by this bill. They do not want that. They do not want the belief amongst people in the street that because they have a civil union not by choice they are in fact having some sort of sexual relationship. That is not the way many people want their relationship to be viewed.

The speaker here is referring to a particular gay couple who live on his street. The reference to a civil union being "not by choice" is difficult to understand as the Act requires registration of the relationship; civil unions cannot be imposed on people. The speaker's reference to "some sort of sexual relationship" suggests something other than the "usual" sort of sexual relationship, something unusual or abnormal. Again, the description of the relationship as for comfort and security, rather than sexual intimacy, erases and makes invisible the sexual intimacy.

Supporters of the Bill also often shied away from any emphasis on gay and lesbian sexuality or intimacy, in at least two ways. First, as in the introductory remarks discussed above, ${ }^{93}$ they often emphasised that civil unions were open to heterosexual couples who did not wish to marry, pointing out that over 300,000 heterosexuals were in de facto relationships. Secondly, they focussed on the characteristics of stability, long-term commitment and love, characteristics that same sex relationships were said to share with opposite sex relationships, rather than on intimacy or sexual orientation, the differences between heterosexual and same sex relationships.

\section{E Assimilation}

The lack of recognition of sexual intimacy in gay and lesbian relationships in the parliamentary debates, combined with the emphasis on positioning those relationships as similar to long-term stable exclusive heterosexual relationships, or marriage, reflects the logic of assimilation, discussed above. ${ }^{94}$ Lesbian and gay relationships will be recognised in the nation and by the state to the extent that they are same as the "gold standard" relationships of the national norm. Any differences from the national norm, the sexual intimacy, will be left unassimilated, or erased, not included in the national norm.

At the same time, Lloyd's analysis of assimilation suggests that the unassimilated differences may be "marked" as local rather than national or universal, primitive or pre-modern rather than

92 Gerrard Eckhoff MP, ACT (7 December 2004) 622 NZPD 17469.

93 See above text accompanying $\mathrm{n} 59$.

94 See above text accompanying n 57. 
modern or progressive. The failure of supporters to positively portray intimate same sex relationships also left open space for opponents of the legislation to characterise the sex of same sex relationships in a category with other unlawful activities. In the debates on the Civil Union Bill, as in the submissions discussed above, ${ }^{95}$ some speakers placed same sex relationships in categories with outlawed activities, such as polygamy and incest. For example, a few speakers argued that recognition of same sex relationships was just the beginning of a slippery slope that would lead to acceptance of polygamy and incest:

If one supports this Bill on the basis of human rights and loving relationships, then why would one not support polygamy? ${ }^{96}$

That plank leads us into Davy Jones' Locker, and we will drown in all sorts of things that as yet we know not of ... the good ship New Zealand is losing its way. They ask whether this bill will lead to polygamy; whether a person could marry more than one person. ... "Is it possible to marry one's son and daughter?", they ask. ${ }^{97}$

Nor do I think that marriage is a human rights issue, because the moment it is, then so is polygamy. Why is the House not pushing a bill along to the select committee today celebrating polygamy? ${ }^{98}$

These statements by opponents of the Bill suggest that there is widely accepted condemnation of polygamy, that everyone knows New Zealand would not want to legally recognise it, and that logically if same sex relationships are in the same category as polygamy then New Zealand should not recognise those either. In the British Empire, Christianity was often associated with Europeans, whiteness, monogamy, progress and civilisation, while polygamy was associated with Asians, premodernity and tribalism. ${ }^{99}$ At the height of the British Empire, monogamy was "instituted as part of England's national identity" 100 in opposition to polygamy, which was foreign, and outside of the empire. These characterisations of polygamy were also evident in New Zealand. ${ }^{101}$ Placing same

95 See above text accompanying n 30 .

96 Sandra Goudie MP, National (7 December 2004) 622 NZPD 17508.

97 Bernie Olgivy MP, United Future (7 December 2004) 622 NZPD 17482.

98 Judith Collins MP, National (24 June 2004) 618 NZPD 13943.

99 Nancy F Cott Public Vows: A History of Marriage and the Nation (Harvard University Press, Cambridge (Mass), 2000) 114-117.

100 Felicity Nussbaum "The Other Woman: Polygamy, Pamela, and the prerogative of empire" in Hendricks Margo and Parker Patricia (eds) Women, "Race", \& Writing in the Early Modern Period (Routledge London, 1994) 149.

101 Nan Seuffert "Shaping the Modern Nation: Colonial Marriage Law, Polygamy and Concubinage in Aotearoa New Zealand" (2003) 7 Law Text Culture 186, 207-212. 
sex relationships in a similar category to polygamy, or not far removed from polygamy on the slippery slope, suggests that they are primitive or pre-modern and foreign, outside of the nation.

If assimilation recognises relationships only to the extent that they are the same as the national norms, then same sex relationships that do not fit into the paradigm of long-term stable exclusive relationships will be positioned as different and outside of the national identity. Both supporters and opponents of the Bill referred to the stereotype of gay males as promiscuous in different ways. However, both seemed to agree that promiscuity, especially among gay men, was a bad thing. Opponents made these arguments: $:^{102}$

I believe that long-term relationships are positive for society, and that promiscuity leads to more problems in our society. I believe that legislation that would perhaps facilitate longer-term legal relationships, longer-term legal commitments, between people would have to be positive for society.

If I were 25 and exploring relationships, I would be very worried. The traditional freedom of the gay community is about to go. If I were a young, gay male, I would be very concerned about this legislation. ${ }^{103}$

The first speaker opposed the Bill on the basis that it looked too much like marriage, although he seems to assume both that the gay community is promiscuous and that the Bill would "perhaps" encourage longer term relationships. In the second quote an opponent of the Bill, who has also called it "ridiculous", argues that gay men should be against it as it restricts their freedom to be promiscuous. There is nothing in the Bill that explicitly restricts sexual freedom, rather it recognises those who wish to formalise relationships, and makes it more difficult to end those relationships. The reference to the promiscuity of the gay community seems gratuitous or scaremongering. Further, it positions the gay community, rather than heterosexual men, as having a "traditional freedom" to explore their sexuality.

Supporters of the Bill applauded it as recognising existing long-term relationships, and as discouraging promiscuity: ${ }^{104}$

Maybe with the passing of this bill and the subsequent civil unions that will follow, we will be able to recognise the long-term committed relationships of gay couples as well, and maybe the beliefs about the promiscuity of homosexuals held by those who would deny them the ability to formalise their relationships will also disappear.

The message, therefore, must be that gays can have legal sexual relationships, but that there is no legal way they can make public commitments to long-term, exclusive relationships. That, I put to this

102 Dr the Hon Lockwood Smith MP, National (7 December 2004) 622 NZPD 17464-65.

103 Hon Bill English MP, National (7 December 2004) 622 NZPD 17467.

104 Moana Mackey MP, Labour (9 December 2004) 622 NZPD 17655. 
Committee, is a position that encourages promiscuity, and that position is in no one's best interest in terms of public health. ${ }^{105}$

The real issue is whether this legislation would affect levels of promiscuity. It is levels of promiscuity that public policy should be concerned with. By the way, the institution of marriage has not eradicated promiscuity completely, but there is no doubt that it has reduced it. Within the homosexual population there are no such incentives. Without a public recognition process, the incentives towards exclusive relationships are lessened. My contention is that this legislation will, over time, reduce multiple relationships within the gay community, with concomitant health and social benefits, because it incentivises long-term, exclusive relationships. ${ }^{106}$

The first quote addresses the assumption of a connection between promiscuity and gay relationships. It suggests that denial of legal recognition of same sex relationships has contributed to the image of gay relationships as promiscuous. Recognition of these relationships will make them visible and contribute to dampening down assumptions of promiscuity. In the last quote the idea is that sexual citizenship, extended through the Civil Union Act 2004, will work to conform the "gay community" to the national standard of long-term exclusive relationships. In the terms of Alan Sinfield's conception of citizenship, discussed above, ${ }^{107}$ sexual citizenship is being deployed to jostle potential deviants into place. This jostling into conformity echoes the concerns among some lesbians and gay men, also discussed above, that recognition would privilege the marriage model over the diversity of relationships currently existing, and not necessarily promiscuous.

\section{F Repressed Stories}

The focus in the debates on long-term stable relationships as a "gold standard", and on marriage as the paradigm for these relationships, was not balanced with recognition of critiques of marriage by feminists and others, although some speakers did mention that not all individual marriages are good ones. Critiques of marriage remained outside of the stories of national identity or collective community told in the debates, erasing the efforts of feminist activists and scholars to address issues of gender power disparities within marriage. One speaker did briefly invoke, or gesture towards, this history and critique, without using it to make any substantive point: ${ }^{108}$

In fact, the big role of this Parliament in terms of women's rights has been to turn marriage from an oppressive institution that treated women as second-class citizens, as property, into one as close to equality as we can get-and there is still a long way to go.

105 Brian Donnelly MP, NZ First (7 December 2004) 622 NZPD 17441.

106 Brain Donnelly MP, NZ First (24 June 2004) 618 NZPD 13946.

107 See above text accompanying n 53.

108 Hon Matt Robson MP, Progressive (24 June 2004) 618 NZPD 13948. 
Feminist scholars are likely to agree that that there is a long way to go, and that the distance receives little attention in debates on same sex marriage. Young and Boyd have argued that in Canada the legal recognition of same sex relationships has "rendered invisible the feminist and other critiques of marriage, family ideology and the domestication of lesbian and gay relationships."109 It is the combination of the valorisation of long-term stable exclusive relationships that are like marriage, the failure to recognise the diversity of relationships, and the erasure of the critiques of marriage that serve to reinscribe and reproduce marriage as a "gold standard" in stories of national identity.

\section{CONCLUSION}

The story of the recognition of lesbian and gay relationships in the Civil Union Act 2004 in New Zealand is a complex one. It is in part a story of the progressive (partial) recognition of human rights in a nation moving forward into a more egalitarian future. It is a story of (partial) inclusion of lesbians and gay men in long-term stable relationships into the collective identity of the nation. By providing legal recognition of same sex relationships it shifts the line of "normal" from a strictly heterosexual/homosexual divide to include those same sex partners willing to embrace civil unions, and willing to accept second-class status. It allows the extension of most of the rights and responsibilities of marriage, and the control and normalisation of marriage, to same sex couples at the same time as it creates a two-tier system. Simultaneously, it responds to some criticisms of marriage by providing a new legal category that some argue may not carry the sexist baggage of marriage. ${ }^{110}$

It is also a story of repressions and exclusions. Some of the opposition to the Civil Union Bill was couched in terms of threats to marriage, the family, the cornerstones of society and civilisation, and the nation. If, as I have argued, the nation is constructed in opposition to what it is not, through repressions and exclusions, it is always necessary to have outsiders counterpoised in opposition to images of the citizen. Some of these outsiders may be more easily absorbed than others. For example, as Alan Sinfield has discussed, ethnicity is less resistant to incorporation in an assimilative model of multiculturalism than "race". The mark of "race" remains, resistant to incorporation. This suggests that the concept of "race" does more ideological work and carries more weight in structuring society, than does ethnicity. ${ }^{111}$ The level of resistance to recognition of civil unions, and the even higher resistance to extending marriage to same sex couples, suggests that the hierarchies of sexual orientation are very important, integral, to structuring society, and that challenging those hierarchies by extending sexual citizenship may present a real threat to existing power structures.

109 Young and Boyd, above n 3, 2, citing Ruthann Robson "Resisting the Family: Repositioning Lesbians in Legal Theory" (1994) 19(4) Signs 975.

110 Kitzinger and Wilkinson, above n 16, 133-135.

111 Sinfield, above n 53, 277. 
The level of opposition to civil unions, and to same sex marriage, therefore represents both the difficulty, and the potential, of sexual citizenship. 